\title{
Epidemiology of Ovarian Cancer: Risk Factors and Prevention
}

\author{
Wasana Sumanasekera*1, Taralein Beckmann ${ }^{1}$, Lynn Fuller ${ }^{1}$, Marilin Castle ${ }^{1}$ and Mary Huff ${ }^{2}$ \\ ${ }^{1}$ Department of Pharmaceutical Sciences, College of Pharmacy, Sullivan University, Louisville, KY. USA
}

${ }^{2}$ Department of Biology, Bellarmine University, Louisville, KY. USA

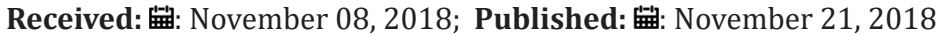

*Corresponding author: Wasana Sumanasekera, Department of Pharmaceutical Sciences, College of Pharmacy, Sullivan University, Louisville, KY. USA

\begin{abstract}
Ovarian cancer is one of the most aggressive reproductive cancers among women. The purpose of this review is to summarize epidemiological factors that contribute to the ovarian cancer risk. This review discusses relevant primary research articles, reviews, cohort studies, population- based studies, pooled data and meta-analysis on ovarian cancer epidemiology and summarizes the positive and negative risk factors for ovarian cancer development. Several search engines including PubMed have been utilized. Epidemiologic factors were discussed under five subheadings including hereditary factors, cancer stem cells, hormonal influences, environmental factors, and lifestyle choices. Hereditary factors such as mutations in BRCA and KRAS genes, hormone levels such as androgens and gonadotrophins, and cytokines have been shown to increase ovarian cancer risk. Ovarian cancer stem cells that reside within the tumor play a role in cancer recurrence and progression. While progesterone shows protective effects, exposure to excessive levels of estrogen may increase the risk for ovarian cancer.

Though the association is somewhat weak, exposure to environmental toxicants could be associated with ovarian carcinogenesis. Cigarette smoking is reported to be associated with subtype specific ovarian cancer. Although the association between general obesity or body mass index and the ovarian cancer risk is inconclusive, central obesity could be a risk factor for ovarian cancer. Consumption of a diet rich in glutathione and other antioxidants, maintaining a healthy weight, and regular exercise may provide protective measures against ovarian cancer. Some of the risk factors for ovarian cancer are sub-type specific and further studies are required to completely understand its complex etiology. Although some reviews are available on this topic, this review is comprehensive and provides novelty as it includes the role of cancer stem cells in ovarian cancer development in addition to other risk factors.

Abbreviations: OC: Ovarian Cancer; HRT: Hormone Replacement Therapy; AHR: Aryl Hydrocarbon Receptor; BRCA: Breast Cancer Gene; NFк $\beta$ : Nuclear Factor Kappa Beta; KRAS: Kirsten Ras Oncogene, PAH: Poly Cyclic Aromatic Hydrocarbons; TCDD: 2,3,7,8-Tetrachlorodibenzodioxin; FOXO1: Fork Head Family Transcription Factor; BAX: BCL-2 Associated X Protein; CAV-1: Caveolin 1; HCG: Human Chorionic Gonadotropin; FSH: Follicle Stimulating Hormone; LH: Luteinizing Hormone; HNPCC: Non-Polyposis Colorectal Cancer; BCL-2: B Cell Lymphoma 2; SHBG: Sex Hormone Binding Globulin; ER: Estrogen Receptor; AR: Androgen Receptor; PR: Progesterone Receptor; IGF: Insulin like Growth Factor; IGFR: Insulin like Growth Factor Receptor; BMI: Body Mass Index; CAG: Cytosine-Adenine-Guanine; IL: Interleukin; CXCR4: Chemokine Receptor; OCSC: Ovarian Cancer Stem Cells; CAFs: Cancer Associated Fibroblasts; FGF: Fibroblast Growth Factor; TGF- $\beta$ : Transforming Growth Factor Beta; PPAR $\gamma$ : Peroxisome Proliferator Activated Receptor Gamma; VEGF: Vascular Endothelial Growth Factor
\end{abstract}

\section{Introduction}

Ovarian Cancer (OC) is a global health crisis and one of the deadly gynecological cancers among women worldwide [1]. Despite OC being only $3 \%$ of all cancer incidents, the mortality rate of the $\mathrm{OC}$ is extremely high making it the fifth leading cause of cancer-related death in women [2-4]. According to 2008-2012 U.S. cancer statistics, 12.7 per 100,000 women were newly diagnosed with ovarian cancer. During that same time period, the death rate was 7.7 per 100,000 women [4,5]. In 2013, the incidence of OC was highest in Caucasian women and lowest in American Indian/Alaska Native women $[6,7]$. Most recently, in 2018 there were about 14,000 of ovarian cancer-related deaths, accounting for $5 \%$ of female cancer deaths have been reported in US [8]. A study analyzing the rate of OC among many ethnic groups residing in the U.S. indicated that the Asian/ Pacific Islanders population had a much lower risk of developing OC [9]. Globally, developed countries have a higher incidence of OC and, by continent; the highest rate is seen in Europe while Africa has the lowest rate [7]. There are three forms of ovarian tumors, each originating from a different cell type; epithelial tumors $(90 \%$ of cases), germ cell tumors ( $5 \%$ of cases), and stromal tumors (5\% of cases) $[4,10]$. 
Epithelial tumors are the most usually diagnosed OC in women $[4,10]$. Different subtypes of epithelial tumors include benign tumors such as serous and mucinous adenomas and cancerous serous, mucinous, clear cell, and endometrioid adenocarcinomas [11]. Germ cell tumors originate from germ cells that can occur at any age but are most prevalent in women in their 20s [4,10]. The three primary types of germ cell tumors include teratomas, dysgerminomas, and endodermal sinus tumors. Stromal tumors include both granulosa cell tumors and sertoli / leydig cell tumors and originate from the connective tissues of the ovaries $[4,10]$. While there are many hypotheses behind the disease, the etiology of ovarian cancer is still unclear [12]. This comprehensive review summarizes recent studies to address the roles of environmental toxicants, lifestyle factors, hereditary factors, and hormones in causing OC risk among women. In addition, the review discusses negative risk factors / OC preventive measures. Although there are reviews available discussing etiologies of OC, many reviews are only focused on areas such as hormonal influences and the hereditary factors.

This unique review includes the role of cancer stem cells in ovarian cancer development. In addition, this review discusses the importance of environmental toxicants and cigarette smoking as causative factors for OC. There are several epidemiological factors that may contribute to the development of ovarian cancer. They include hereditary factors such as family history, presence of breast cancer associated gene (BRCA) 1 and 2 mutations, age, estrogen influences such as early menarche, menopause after 52 years of age as well as environmental risk factors and life style choices such as exposure to PAH, cigarette smoking, and obesity [12]. All these factors have an association with fluctuations in reproductive hormones. Chemo preventive measures/negative risk factors include progesterone, dietary measures and healthy life styles. Ovarian cancer stem cells play a major role in ovarian cancer recurrence.

\section{Contribution of Genetic / Hereditary Factors to Ovarian Carcinogenesis}

Genetic mutations are the greatest risk factor for the development of OC, with $10-15 \%$ of women diagnosed having a hereditary link 4. A mutation in the breast cancer genes BRCA1 or BRCA2 accounts for $5-10 \%$ of all OC cases [4]. For BRCA1 mutation carriers, the average cumulative risk by age 70 is estimated to be $59 \%$. For BRCA2 carriers, the risk is estimated to be $16.5 \%$ [13]. KRAS gene mutations have also been associated with well-differentiated mucinous ovarian carcinomas [14], and $11 \%$ of epithelial ovarian cancers had KRAS mutations [14]. Other genetic risk factors for the development of OC include a $12 \%$ increased risk for patients with Hereditary Non-Polyposis Colorectal Cancer (HNPCC or Lynch Syndrome), a $1.4 \%$ increased risk for women with a first-degree relative diagnosed with $\mathrm{OC}$, and a previous history of breast, uterine, colon or rectal cancer $[4,10]$

\section{Contribution of Ovarian Cancer Stem Cells (OCSCs) to Ovarian Carcinogenesis}

Small populations of cells located inside the ovarian tumor with self-renewal and differentiation capabilities are called ovarian can- cer stem cells (OCSCs) $[2,15]$. This OCSC niche could be originated from fallopian tubes $[16,17]$ as this was the site where ovarian cancer reported to be originated [18]. These OCSCs play a major role in cancer pathogenesis [16-20], and drug resistance [19,21,22] leading to cancer recurrence following treatment [15,23,24]. OCSCs contributes to ovarian cancer progression via interacting with several other cell types including cancer associated fibroblasts (CAFs) and carcinoma associated mesenchymal stem cells (CA- MSCs) in the tumor microenvironment [2]. CAFs aid OCSC self-renewal via activation of the fibroblast growth factor (FGF) signaling $[25,26]$ through FGF receptors (FGFR2) that are expressed in the OCSCs [26]. FGF induces vascular endothelial growth factor (VEGF) secretion causing angiogenesis, the new blood vessel formation in tumors [27]. VEGF-A, a member of the VEGF family, activates OCSCs leading to ovarian cancer progression [28].

CA-MSCs can differentiate into other types of tumor microenvironment cells such as fibroblasts and adipocytes [29]. They induce OCSC proliferation via upregulation of tumor growth factor $\beta$ (TGF- $\beta$ ) / BMP signaling [30]. In addition, OCSCs aid differentiation of monocytes to tumor associated macrophages termed M2 macrophages, another cell type present in the tumor microenvironment $[31,32]$. These M2 macrophages can secrete many factors including VEGF, cytokines, peroxisome proliferator activated receptor $\gamma$, and TGF- $\beta$ [31-36]. OCSCs influence tumor growth and metastasis via activation of cytokines including IL-17 [37] and IL-10 [31,32]. IL-17 receptors are reported to be present in OCSCs [37]. Upregulation of these cytokines and other factors such as VEGF, PPAR $\gamma$, and TGF- $\beta$ lead to OCSC self-renewal, which is partially mediated by $N F \kappa \beta$, $\operatorname{PPAR} \gamma$, and P-38 MAPK signaling [32,37].

\section{Contribution of Reproductive Factors \& Other Hormones to Ovarian Carcinogenesis}

Hormonal Risk Factors and Hormone Replacement Therapy (HRT): Epidemiological studies have identified a number of hormone-related risk factors [12] for OC including early age of menarche [38,39], late age of menopause, null parity, never taking oral contraceptives [38-41], and having received hormone replacement therapy (HRT) [39,41-43]. Several studies have shown that post-menopausal estrogen replacement therapy, regardless of the presence of progestin, increases the risk of developing OC [4448]. This risk is higher with estrogen-only HRT [49]. A recent study from Morch et al. concluded that HRT-related OC risk is dependent on type of the tumor [50]. Ovarian endometriosis has also been associated with increased risk for OC [51-53].

On the other hand, women with unilateral ovariectomy $[39,54]$, longer duration use of oral contraceptives $[39,54,55]$ and a higher number of full-term pregnancies [39] had a lower risk of developing OC. The relationship between breast feeding and ovarian cancer development is inconclusive. Some cohort studies and population-based studies suggest that women who breast fed for a period of 6-12 months shows decreased incidents of ovarian cancer $[42,56]$. Other cohort studies that investigated reproductive factors and ovaian cancer occurance concluded that breast feeding is not associated with ovarian cancer development [54,57]. There is in- 
conclusive evidence on polycystic ovarian syndrome (POS) as a risk factor for the ovarian cancer. Some studies suggest that POS is a risk factor for ovarian cancer [58,59] and the involvement of POS in ovarian cancer development could be specific to ovarian cancer subtype [58]. The association between POS and ovarian cancer can be mitigated by factors such as women's leanness and LH hormone levels [59]. Few other studies suggest no association between POS and ovarian cancer $[60,61]$. However, POS is significantly associated with endometrial cancer [60-62].

Role of Progesterone: Progesterone shows a protective effect against ovarian carcinogenesis [12,63]. High levels of progesterone during pregnancy and progestin-containing oral contraceptives are associated with a decreased risk for OC [54,64.] Progesterone has been shown to suppress cellular growth in ovarian cancer cells by activating apoptosis [65-70] and decreasing cyclin dependent kinase activity resulting in a reduced number of transformed cells [71]. The tumor suppressive effects of progesterone occur via activation of the tumor suppressor / pro-apoptotic genes including P-53, Cav-1, BAX $[70,72]$ and down regulation of anti-apoptotic genes such as BCL-2 [70,72]. Further, progesterone inhibits cell

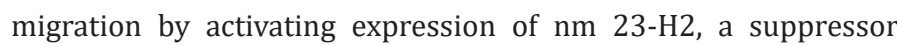
protein that inhibits cell motility [72-74] and inhibits metastasis in OC $[73,74]$.

More recently, it was shown that progesterone can upregulate F0X01 transcription, a fork head transcription factor that in turn, increases the rate of senescence [75]. These studies provide accumulative evidence that progesterone may be important in controlling cellular growth, and that dysregulation of progesterone could greatly reduce these activities resulting in increased cancer growth and metastasis. In fact, several studies have shown that progesterone receptor expression is down regulated in many ovarian tumors [76,77], while PR expression is associated with improved disease-specific survival [78].

Role of Estrogen: Estrogen receptors $\alpha$ and $\beta$ are expressed in normal ovarian cells [76], and though it is possible that estrogens stimulate ovarian carcinogenesis through its proliferation promoting effects [49,79], estrogen's involvement in ovarian cancer is inconclusive. However, at high concentrations estrogens are reported to be involved in the early steps of malignant transformation [63]. Estrogen has been shown to increase cell motility and metastasis via down regulating $\mathrm{nm} 23-\mathrm{H} 2$ expression and upregulating PI3 kinase / AKT phosphorylation pathway [73] and to induce early onset of ovarian tumors and decrease survival in a mice model [79]. In another study using fluorescent ER negative and ER positive human epithelial OC cells, it was observed that estrogen significantly increased the size of tumors and promoted lymph node metastasis [80]. Women who are at high risk for developing OC may choose to have a hysterectomy or tubal ligation in order to reduce their risk [81-85]. The treatment of OC cells with estrogen caused attenuation of chemo protective effects of progesterone via decreasing expression of progesterone receptors at the transcriptional level [86].

Role of Androgen: Like progesterone, elevated androgens may increase the risk of ovarian cancer [12,63]. Epidemiologic data implicate that abnormal androgen homeostasis could promote aggressive epithelial ovarian cancer biology, especially with elevated androgenicity $[12,63]$. Obesity may induce elevated androgenicity since previous studies have shown that increased adipose tissue can stimulate increased circulating levels of free testosterone and decreased sex hormone binding globulin levels (SHBG) [87]. One of the pathologic prognostic factors for ovarian cancer development is represented by the length of the cytosine-adenine-guanine (CAG) repeat sequence on exon 1 of the androgen receptor (AR) [87]. According to several studies, obesity and a short AR allele type $(\leq 19$ CAG repeats) were identified as being associated with poor survival or a poor prognostic factor in advanced stages of the disease [87]. Based on a retrospective review performed on 81 patients with papillary serous epithelial ovarian cancer, the combination of short AR allele type and obesity (BMI $>25$ ) correlated with decreased overall survival [87], which further supports that an abnormal androgen environment may contributes to aggressive epithelial ovarian tumor biology $[12,87]$. Future studies should be directed to explore the potential use of anti-androgen and weight management in the treatment of ovarian cancer.

Role of Gonadotrophins: According to the gonadotropin hypothesis, ovarian cancer develops from excess stimulation of ovarian tissue by the pituitary gonadotropins, follicle stimulating hormone (FSH), and luteinizing hormone (LH) [12,88]. Most ovarian cancer patients are diagnosed during the postmenopausal stage when circulating FSH and LH levels remain high due to the lack of negative feedback by ovarian steroids [88]. Gonadotropins (LH and FSH) are involved in the elevated serum beta human chorionic gonadotropin (b-hCG), activation of oncogenic pathways, inhibition of cellular apoptosis, and aberrant p53 tissue expression [12], all which lead to advanced stage, grade, and poor prognosis of ovarian cancer. It is also well established that pregnancies and oral contraceptives have protective effects by suppressing gonadotropin secretion by the pituitary gland [88]. The secretion of these hormones is controlled by gonadotropin releasing hormone (GnRH). Ovarian cancer risk could be associated with variation in gonadotropin signaling pathway genes including GnRH [88]. However, further evaluation is required to conclude the genetic association with the ovarian cancer risk.

Role of Insulin and Insulin-like Growth Factor-1 (IGF1): Both insulin [89-91] and IGF-1 [91,92] are shown to exert proliferative and anti-apoptotic effects that could lead to several cancers [93-95]. Insulin and IGF-1 mediated downstream signaling via binding to IGF-1 receptor, leads to synthesis of other hormones including androgens, which may also induce ovarian cancer development $[63,93]$. At this time, however, there is not enough direct evidence to include insulin or IGF-1 as risk factors for OC development [63].

\section{Role of Inflammatory Cytokines}

Inflammatory cytokines / chemokines and the chemokine receptor CXCR are known to be involved in ovarian carcinogenesis [96]. Increased expression of interleukin 8 (IL-8) / CXCL-8 and IL-8 receptors are expressed in serous ovarian carcinomas [96]. Il-1beta, which is secreted by ovarian cancer cells, is reported to cause 
ovarian tumorigenesis via suppressing the p53 protein [97]. IL-6 also significantly contributes to the progression of ovarian carcinogenesis $[98,99]$. Antibodies raised against these interleukins can be used as a therapeutic tool to treat OC [96-98]. These cytokines have been shown to induce Nuclear Factor Kappa beta (NFK $\beta$ ) mediated signaling, which may serve as a link between inflammation and the development of ovarian cancer [12]. NFK $\beta$ serves many functions such as mediating the effects of sex steroid hormones, tumor invasion, adhesion, and metastasis [12].

\section{Contribution of Environmental Risk Factors to Ovarian Carcinogenesis}

Polycyclic Aromatic Hydrocarbons (PAHs): Polycyclic aromatic hydrocarbons (PAHs) are a class of chemicals known to be environmental pollutants, with some being classified as carcinogens [100-103]. Exposure to PAHs can occur through diet, the environment, or through occupational sources $[100,102,104]$. Environmental toxicity depends on the size of the particulates in the environment [105] and can occur by differing degrees since PAHs are produced through the burning of natural compounds such as wood, coal, gasoline, diesel and tobacco smoke [100,104]. Smaller sized particulates less than $10 \mu \mathrm{M}$ (PM10) to $2.5 \mu \mathrm{M}$ (PM2.5) have a higher probability of containing PAHs. These are more likely to be absorbed through the alveoli of the lungs, increasing risk for not only localized toxicity but systemic toxicity as well [105]. PAHs can also be absorbed through the skin $[106,107]$ and GI tract $[108,109]$. Urban areas have higher concentrations of PAHs because of increased traffic congestion leading to greater exposure of motor vehicle exhaust $[110,111]$.

Areas with higher concentrations of smaller particulates (PM2.5) have been shown to result in an increased risk of mortality from OC $[110,112]$. A study that investigated OC mortality in women who live near Spanish industries revealed that OC-related mortality was significantly higher in women residing near industries that release PAHs, and metals [112]. Cigarette smoke contains several known carcinogens including PAHs [113-115]. PAHs form DNA adducts that directly cause cellular mutations, which could result in tumor formation [116]. PAH-DNA adducts are indicators to assess the degree of carcinogen exposure $[116,117]$. Adduct concentrations are higher in smokers compared to non-smokers [116,117]. Cervical tissue collected from smokers and non-smokers revealed a greater number of PAH (benzo(a)pyrene diol-epoxide)-DNA adducts in tissue from smokers indicating the involvement of PAH-induced genotoxicity in the female reproductive tract [118] that eventually led to carcinogenesis. PAH exposure is a known risk factor for breast cancer development [119-121].

Studies based on ovarian cells exposed to varying levels of PAHs have resulted in ovarian tumor growth and primary ovarian insufficiency [104]. Benzo (a) pyrene is reported to cause ovarian tumorigenesis in mice that are deficient in glutathione [104], a critical component for the detoxification of PAH metabolites. TCDD 2,3,7,8-Tetrachlorodibenzo-p-dioxin, also known as TCDD or dioxin, is an environmental contaminant best known for its use in the Vietnam War as the herbicide agent orange [122-124]. TCDD per- sists in the environment and bio accumulates [122]. Exposure to TCDD primarily occurs through the diet [123] and is classified by the International Agency for Research on Cancer (IARC) as a carcinogen in animal models [125]. TCDD induces hepatic carcinogenesis in rats [126]. TCDD may be a human carcinogen although its ability to induce human cancers is still inconclusive [127]. In humans, TCDD has been shown to cause hyperkeratosis of skin $[128,129]$, wasting syndrome [130-132], and reproductive, developmental, and immune related complications [125].

Chronic exposure to TCDD has been shown to induce ovarian tumor growth in female Sprague Dawley rats [133]. In a Caov-3 OC cell line, TCDD exposure resulted in increased expression of TCDD and ER-linked genes [134]. It has also been shown to reduce the number of ovarian follicles, which could result in infertility [135]. TCDD has been shown to exert its effects via binding to the aryl hydrocarbon receptor and modulating downstream PI3Kinase and MAPK (ERK) signaling [128,136]. In mouse epithelial OC cells, TCDD activates Protein kinase C delta, which is involved in cell proliferation, leading to OC progression [132]. In addition, TCDD has been shown to induce human breast cancer cell growth via inhibiting apoptosis in human mammary epithelial cells [137]. However, some studies show negative association between TCDD and ovarian cancer progression. TCDD shows anti-proliferative effects in OVCAR-3 ovarian cancer cell line [138]. Therefore, more evidence is needed to conclude TCDD's association with ovarian cancer.

\section{Contribution of Lifestyle Factors to Ovarian Carcinogen- esis}

Cigarette smoking: The correlation between cigarette smoking and the development of OC has been inconclusive. According to the International Agency for Research on Cancer (IARC) and the World Health Organization (WHO), there is insufficient evidence to conclude any effect of smoking on OC risk [10]. A number of population based studies utilizing OC patients has assessed the risk of cigarette smoking on different OC types including invasive and borderline cancer, mucinous, epithelial, and serous tumors. While some studies have suggested that an association exists between smoking and OC, others showed no relationship. It has been suggested that the association of smoking and OC risk may be based on the histological type of the ovarian cancer [56]. In a study using 558 epithelial (boarder line and invasive) OC patients, active smokers showed an increased risk for borderline serous cystadenomas but not with borderline mucinous cystadenoma and invasive ovarian cancers [139]. Long-term smokers or previous long-term smokers of 20 years or more showed a decreased risk of invasive OC development [139]. In agreement with Goodman et al. several other studies have concluded that there is no significant correlation between active cigarette smoking and development of epithelial tumors $[56,140]$.

In contrary to the study by Goodman et al. other population based, case controlled studies concluded that both active and longterm cigarette smoking increases ovarian epithelial tumors including mucinous tumors and borderline OC [141]. Women who started smoking at a younger age (less than 20), and smoked more than 
20 years showed a higher risk of developing epithelial OC [141]. Borderline tumor risk increased for those who had smoked or were previous smokers within the past 15 years and those with a longer history of total pack-years of smoking [142]. The number of mucinous and serous tumor cases were also found to be greater in women who had a longer history of smoking, greater pack-year history, and if they were active smokers within 15 years of diagnosis [142]. There were no increases in endometrial, clear cell, or other histologic subtypes of OC associated with smoking [142]. According to a recent meta-analysis based on 51 epidemiological studies, however, smoking is only associated with mucinous ovarian cancers, mainly tumors of borderline malignancy [143]. According to this meta-analysis, there was no positive correlation between cigarette smoking and occurrence of serous or any other form of tumorigenesis / carcinogenesis [143].

Obesity and Physical Activity: The association between the body mass index (BMI) or general obesity and ovarian cancer occurrence is inconclusive. Obesity could be weakly associated with OC and this association is OC subtype specific [144,145]. Based on few cohort studies, a high body mass index greater than 30 among post-menopausal women has been shown to be associated with increased OC development $[146,147]$. According to an original research study using genetically engineered mouse model of serous ovarian cancer, the authors have concluded that the greater body mass index increases ovarian cancer specific mortality [148] likely due to the production of estrogen by the increased adipose tissue $[4,145]$. In addition, using a p53, BRCA1 knock-out mouse model, Makowski and colleagues concluded that obesity increases the aggressiveness of tumors [148]. However, some population based prospective cohort studies suggest there is no association between general obesity (body fat percentage) or BMI and ovarian cancer occurrence $[149,150]$.

Based on population based prospective cohort studies, abdominal adiposity / central obesity as measured by waist to hip ratio [149] and weight gain, but not overall obesity, are risk factors for ovarian cancer development [151]. The influence of physical activity as a protective measure for ovarian cancer remains inconclusive. However, based on some case -controlled studies, meta-analysis and epidemiological reviews, increased physical activity attenuates obesity and possibly a negative risk factor / preventive measure for OC development [152-156]. In addition, lack of physical activity is reported to associate with increased risk of mortality in patients suffering from invasive epithelial ovarian cancer [157] and participating in physical activity prior to ovarian cancer diagnosis lowers the risk of mortality [158]. Lack of physical activity and obesity also worsen the quality of life in ovarian cancer survivors [159]. However, some population- based cohort studies do not suggest a protective role of physical activity for ovarian carcinogenesis [160-162].

Dietary Factors and Chemoprevention: Although there are no reports linking consumption of a high fat diet or grilled meat with OC risk [163], consumption of some food items, such as diets rich in fat content [164,165], preservatives [166], and grilled meat [167] increases the risk for many other cancers in both human and animal models. In contrast, diets rich in cruciferous vegetables [168], green tea $[169,170]$, soy products [171,172], and mushrooms $[173,174]$ have been reported to decrease OC risk. Cruciferous vegetables are rich in glutathione, which eliminates carcinogenic metabolites from the body via Phase 2 drug biotransformation reactions [175]. They are also rich in isothiocyanates, which may induce apoptosis in certain cell lines [168]. Soy products, which are rich in phytoestrogen such as genistein [176], can inhibit carcinogenesis via many mechanisms including inducing cell death [176], inhibiting DNA damage, and inactivating carcinogens in animal models [168].

Based on many prospective cohort studies, meta-analysis and population-based case-controlled studies; there is no association between alcohol consumption and OC risk [177-181]. However, a few studies show weak association between alcohol consumption and ovarian cancer risk, which is dependent upon several other factors such as alcohol type, tumor invasiveness, and, the type of the cancer $[182,183]$. There is some evidence to suggest that caffeine is inversely associated with OC risk $[140,184]$. Caffeine also has anti-proliferative effects in A2780 human OC cells [185,186]. However, additional studies have shown no association between caffeine consumption and OC risk [187-189]. Therefore, the association between caffeine consumption and the ovarian cancer risk is inconclusive.

\section{Discussion}

OC is one of the most aggressive reproductive cancers and it can be fatal to women if not diagnosed and treated early. Here, we have provided a comprehensive review discussing the major risk factors for the development of ovarian cancer. Please note that some of these risk factors could be specific to ovarian cancer sub-types. Based on epidemiologic studies and predicted by several hypotheses, the positive and negative risk factors (preventative measures) for ovarian cancer development were elucidated and summarized in (Table 1). While several of the risk factors show strong correlations, some risk factors remain weakly associated and some of the associations are inconclusive (Table 1). Ovarian tumorigenesis occurs via several possible mechanisms and pathways, which are summarized in (Figure 1). Hereditary factors such as genetic mutations in proto oncogenes and tumor suppressor genes play a major role in many different cancers [190,191]. BRCA1, BRCA2, and KRAS gene mutations are seen predominantly in ovarian carcinogenesis. Cancer stem cells play a crucial role in ovarian cancer pathogenesis and recurrence. Hormones such as androgens, high levels of estrogens, and gonadotrophins are positively correlated with ovarian cancer and are thought to exert their effects by activating cellular proliferation, inhibiting apoptosis, and activating oncogenic pathways. 
Table 1: Summary of positive and negative risk factors for the ovarian cancer development.

\begin{tabular}{|c|c|c|}
\hline Risk Factors & Mechanism / Details & References \\
\hline Genetic mutations & $\begin{array}{c}\text { Increased risk with mutations in BRCA1, BRCA2, KRAS genes Increased risk for patients } \\
\text { diagnosed with breast, colon, rectal, and Hereditary non -polyposis colorectal (HNPC) } \\
\text { cancer }\end{array}$ & {$[1,6,10,11]$} \\
\hline Cancer stem cells & $\begin{array}{c}\text { Play a role in cancer pathogenesis via activating FGF, VEGF, PPAR, TGF } \beta, \text { P-38 MAPK } \\
\text { signaling and activation of IL-17 }\end{array}$ & [15-37] \\
\hline $\begin{array}{l}\text { Hormones } \\
\text { Estrogen }\end{array}$ & $\begin{array}{l}\text { High levels may increase risk via estrogen induced cell proliferation Inconclusive / weak } \\
\text { association }\end{array}$ & {$[49,63,73]$} \\
\hline *Progesterone & Protective effect through suppression of cellular growth and Inhibition of cell migration & [65-74] \\
\hline HRT & Inconclusive, yet many studies support long term HRT increases risk & {$[39,41-53]$} \\
\hline Androgen & Increased risk due to androgen induced cellular proliferation & {$[12,63]$} \\
\hline Gonadotropins & FSH and LH increase risk by activating oncogenic pathways & {$[12,88]$} \\
\hline Insulin and IGF-1 & Inconclusive / possible association & {$[63,89-95]$} \\
\hline Cytokines and NFK $\beta$ & IL-8, IL-1 beta, IL-6, and NFK $\beta$ are linked to increased risk & {$[12,96-99]$} \\
\hline $\mathrm{PAH}$ & $\begin{array}{l}\text { PAH-induced gene mutations leading to tumor formation Increased risk of ovarian } \\
\text { cancer related mortality }\end{array}$ & {$[110,112,116]$} \\
\hline TCDD & Ovarian tumor growth in animal models via TCDD -induced Modulation of AHR signaling & {$[128,132-138]$} \\
\hline Cigarette smoke & $\begin{array}{l}\text { increased risk of developing mucinous epithelial ovarian cancer Weak / inconclusive } \\
\text { association in other ovarian cancer subtypes }\end{array}$ & {$[10,56,141-143]$} \\
\hline Obesity & $\begin{array}{l}\text { Inconclusive / weak association, Increases ovarian cancer risk Possibly via production of } \\
\text { estrogen by the adipose tissue }\end{array}$ & {$[5,144-151]$} \\
\hline $\begin{array}{l}\text { Dietary factors } \\
{ }^{*} \text { Glutathione }\end{array}$ & $\begin{array}{l}\text { Glutathione rich food (cruciferous vegetables, green tea soy and mushroom) } \\
\text { consumption leads to decreased risk }\end{array}$ & [168-176] \\
\hline High fat diet & Inconclusive. However, high fat diet increases other risk factors Such as obesity & [164-165] \\
\hline *Physical activity & Act as a negative risk factor via reducing central obesity & [152-159] \\
\hline Alcohol & No association between alcohol consumption and ovarian cancer risk & {$[177-181]$} \\
\hline Caffeine & Inconclusive association & {$[140,184-189]$} \\
\hline
\end{tabular}

Note: *negative risk factor

AHR =Aryl Hydrocarbon receptor, PAH = Polycyclic Aromatic Hydrocarbons, TCDD = 2,3,7,8 -Tetrachlorodibenzo-p-dioxin, HRT = Hormone Replacement Therapy, IL=Interleukin, FSH=Follicular Stimulating Hormone, $\mathrm{LH}=$ Luteinizing hormone, NFK $\beta=$ Nuclear Factor Kappa Beta. 


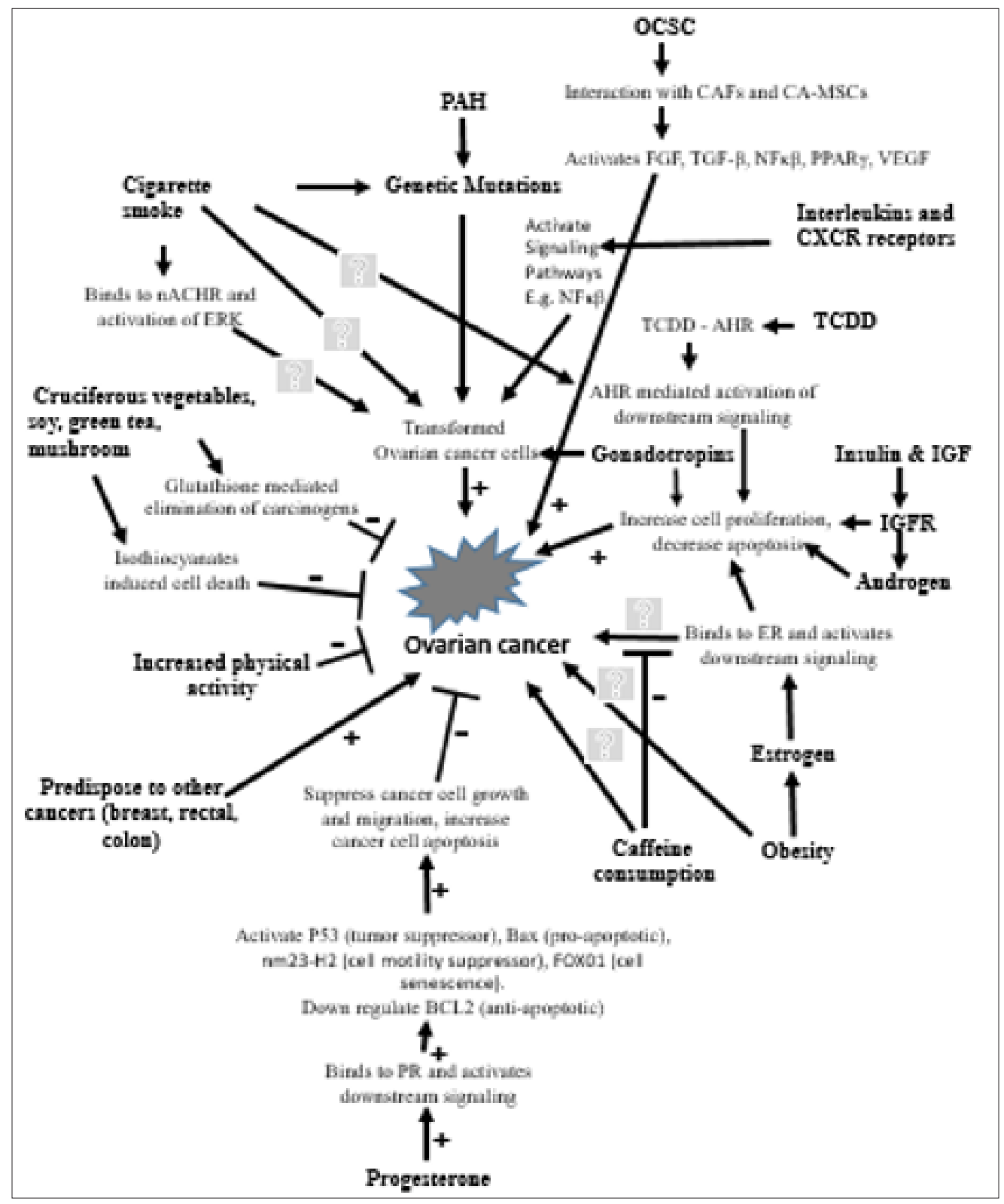

Figure 1: Model summarizing mechanisms that lead to ovarian cancer development and preventive measures. OCSC mediated signaling, hereditary factors, hormonal influences (except progesterone), Cytokines, environmental contaminants (TCDD, PAH) are causative factors. Glutathione rich food, isothiocyanates, physical activity and progesterone inhibits ovarian carcinogenesis. The involvement of cigarette smoking, obesity, and caffeine consumption is not clear. - sign and - $\mid=$ inhibition / down regulation. $+=$ activation of a pathway. ?= unknown / not clear.

Progesterone, on the other hand, has a protective effect against OC, most likely by activating tumor suppressor genes, pro-apoptotic genes, and cell senescence genes. Cytokines such as IL-1 $\beta$, IL8, and IL6 contribute to OC development mainly via activating NFK $\beta$ mediated downstream signaling that mediates several functions including modulation of hormone levels, tumor invasion, and metastasis (Figure 1). Exposure to environmental toxicants such as TCDD contributes to ovarian carcinogenesis via AhR mediated signaling that leads to anti-apoptotic effects. Exposure to PAH increased ovarian cancer risk via PAH mediated genetic changes that led to transformation of ovarian cells. Life style choices such as cig- arette smoking contributes to sub type specific ovarian cancer risk via many possible pathways including nACHR mediated activation of ERK signaling, genetic mutations etc. (Figure 1). Although the association between general obesity or body mass index and the ovarian cancer risk is inconclusive, central obesity could be a risk factor for ovarian cancer possibly via production of estrogen by the adipose tissue. Consumption of diets rich in glutathione provides protection against $\mathrm{OC}$ via glutathione mediated elimination of carcinogenic metabolites. Consumption of soy products is negatively associated with OC development via many mechanisms including inhibition of DNA damage. 


\section{Conclusion}

In conclusion, multiple factors, such as genetic/ hereditary factors, cancer stem cells, exposure to androgens, high levels of estrogens, gonadotropins, and inflammatory cytokines have been shown to increase the risk of developing OC. In addition, accumulating evidence suggests that exposure to a number of environmental toxicants can increase risk for OC. Progesterone shows protection against ovarian cancer. Choosing healthy lifestyles such as diets rich in glutathione and other antioxidants, maintaining a healthy weight, and regular exercise may provide protective measures against OC. All the risk factors that contribute to ovarian cancer are summarized in Table 1. The mechanistic pathways, which these risk factors contribute to ovarian cancer development and chemoprevention are summarized in (Figure 1).

\section{Acknowledgement}

We would like to acknowledge Dr. Lindsay Barr and Dr. Vikoriya Shekhovtsova for helping us with the literature search.

\section{References}

1. Matz M, Coleman MP, Carreira H, Salmeron D, Chirlaque MD, et al. (2017) Worldwide comparison of ovarian cancer survival: Histological group and stage at diagnosis (CONCORD-2). Gynecologic oncology 144(2): 396-404.

2. Varas Godoy M, Rice G, Illanes SE (2017) The Crosstalk between Ovarian Cancer Stem Cell Niche and the Tumor Microenvironment. Stem cells international 2017: 5263974.

3. Siegel RL, Miller KD, Jemal A (2015) Cancer statistics, 2015. CA. a cancer journal for clinicians 65(1): 5-29.

4. Goff BA, Balas C, Tenenbaum C (2013) Ovarian cancer national alliance a report of the 2012 Consensus Conference on Current Challenges in ovarian cancer. Gynecologic oncology 130(1): 9-11.

5. Cronin KA, Ries LA, Edwards BK (2014) The Surveillance, Epidemiology, and End Results (SEER) Program of the National Cancer Institute. Cancer 120 Suppl 23: 3755-3757.

6. Muir CS, Parkin DM (1992) Cancer Incidence in Five Continents. Classification. IARC Sci Publ 120:45-173.

7. Lingeman $\mathrm{CH}$ (1983) Environmental factors in the etiology of carcinoma of the human ovary: a review. Am J Ind Med 4(1-2): 365-379.

8. Torre LA, Trabert B, DeSantis CE, Miller KD, Samimi G, et al. (2018) Ovarian cancer statistics, 2018. CA: A cancer journal for clinicians 68(4): 284-296.

9. Miller BA, Chu KC, Hankey BF, Ries LA (2008) Cancer incidence and mortality patterns among specific Asian and Pacific Islander populations in the U.S. Cancer causes \& control : CCC 19(3): 227-256.

10. Humans IWGotEoCRt (2004) Tobacco smoke and involuntary smoking. IARC monographs on the evaluation of carcinogenic risks to humans / World Health Organization, International Agency for Research on Cancer 83: 1-1438.

11. Yamashita T, Yaginuma Y, Yamashita K, Fujita M, Ishikawa M (1996) DCC gene alterations in histological types and clinical stages of epithelial ovarian cancer. International journal of oncology 9(2): 291-296.

12. Gharwan H, Bunch KP, Annunziata CM (2015) The role of reproductive hormones in epithelial ovarian carcinogenesis. Endocrine-related cancer 22(6): 339-363.

13. Mavaddat N, Peock S, Frost D, Ellis S, Platte R, et al. (2013) Cancer risks for BRCA1 and BRCA2 mutation carriers: results from prospective analysis of EMBRACE. Journal of the National Cancer Institute 105(11): 812-822.

14. Nodin B, Zendehrokh N, Sundstrom M, Jirstrom K (2013) Clinicopathological correlates and prognostic significance of KRAS mutation status in a pooled prospective cohort of epithelial ovarian cancer. Diagnostic pathology 8: 106.

15. Foster R, Buckanovich RJ, Rueda BR (2013) Ovarian cancer stem cells: working towards the root of stemness. Cancer letters 338(1): 147-157.

16. Flesken-Nikitin A, Hwang CI, Cheng CY, Michurina TV, Enikolopov G, et al. (2013) Ovarian surface epithelium at the junction area contains a cancer-prone stem cell niche. Nature 495(7440): 241-245.

17. Paik DY, Janzen DM, Schafenacker AM, Velasco VS, Shung MS, et al. (2012) Stem-like epithelial cells are concentrated in the distal end of the fallopian tube: a site for injury and serous cancer initiation. Stem cells 30(11): 2487-2497.

18. Erickson BK, Conner MG, Landen CN (2013) The role of the fallopian tube in the origin of ovarian cancer. Am J Obstet Gynecol 209(5): 409414.

19. Medema JP (2013) Cancer stem cells: the challenges ahead. Nature cell biology 15(4): 338-344.

20. Hu L, McArthur C, Jaffe RB (2010) Ovarian cancer stem-like sidepopulation cells are tumourigenic and chemoresistant. British journal of cancer 102(8): 1276-1283.

21. Dean M, Fojo T, Bates S (2005) Tumour stem cells and drug resistance. Nature reviews Cancer 5(4): 275-284.

22. Alvero AB, Chen R, Fu HH, Montagna M, Schwartz PE, et al. (2009) Molecular phenotyping of human ovarian cancer stem cells unravels the mechanisms for repair and chemoresistance. Cell cycle 8(1): 158-166.

23. Agarwal R, Kaye SB (2003) Ovarian cancer: strategies for overcoming resistance to chemotherapy. Nature reviews Cancer 3(7): 502-516.

24. Steg AD, Bevis KS, Katre AA, Ziebarth A, Dobbin ZC, et al. (2012) Stem cell pathways contribute to clinical chemoresistance in ovarian cancer. Clinical cancer research 18(3): 869-881.

25. Zhang Y, Tang H, Cai J, Zhang T, Guo J, et al. (2011) Ovarian cancerassociated fibroblasts contribute to epithelial ovarian carcinoma metastasis by promoting angiogenesis, lymphangiogenesis and tumor cell invasion. Cancer letters 303(1): 47-55.

26. Yasuda K, Torigoe T, Mariya T, Asano T, Kuroda T, et al. (2014) Fibroblasts induce expression of FGF4 in ovarian cancer stem-like cells/cancerinitiating cells and upregulate their tumor initiation capacity. Laboratory investigation; a journal of technical methods and pathology 94(12): $1355-1369$

27. Carmeliet $P$ (2005) VEGF as a key mediator of angiogenesis in cancer. Oncology 69(S3): 4-10.

28. Jang K, Kim M, Gilbert CA, Simpkins F, Ince TA, et al. (2017) VEGFA activates an epigenetic pathway upregulating ovarian cancer-initiating cells. EMBO molecular medicine 9(3): 304-318.

29. Coffman LG, Choi YJ, McLean K, Allen BL, di Magliano MP, et al. (2016) Human carcinoma-associated mesenchymal stem cells promote ovarian cancer chemotherapy resistance via a BMP4/HH signaling loop. Oncotarget 7(6): 6916-6932.

30. McLean K, Gong Y, Choi Y, Deng N, Yang K, et al. (2011) Human ovarian carcinoma-associated mesenchymal stem cells regulate cancer stem cells and tumorigenesis via altered BMP production. The Journal of clinical investigation 121(8): 3206-3219.

31. Zhang Q, Cai DJ, Li B (2015) Ovarian cancer stem-like cells elicit the polarization of M2 macrophages. Molecular medicine reports 11(6): 4685-4693.

32. Deng X, Zhang P, Liang T, Deng S, Chen X, et al. (2015) Ovarian cancer stem cells induce the M2 polarization of macrophages through the 
PPARgamma and NF-kappaB pathways. International journal of molecular medicine 36(2): 449-454.

33. Coffelt SB, Hughes R, Lewis CE (2009) Tumor-associated macrophages: effectors of angiogenesis and tumor progression. Biochim Biophys Acta 1796(1): 11-18.

34. Quatromoni JG, Eruslanov E (2012) Tumor-associated macrophages: function, phenotype, and link to prognosis in human lung cancer. American journal of translational research 4(4): 376-389.

35. Colvin EK (2014) Tumor-associated macrophages contribute to tumor progression in ovarian cancer. Frontiers in oncology 4: 137.

36. Medrek C, Ponten F, Jirstrom K, Leandersson K (2012) The presence of tumor associated macrophages in tumor stroma as a prognostic marker for breast cancer patients. BMC cancer 12: 306.

37. Xiang T, Long H, He L, Han X, Lin K, et al. (2015) Interleukin-17 produced by tumor microenvironment promotes self-renewal of CD133+ cancer stem-like cells in ovarian cancer. Oncogene 34(2): 165-176.

38. Jordan SJ, Webb PM, Green AC (2005) Height, age at menarche, and risk of epithelial ovarian cancer. Cancer epidemiology, biomarkers \& prevention 14(8): 2045-2048.

39. Li K, Husing A, Fortner RT, Tjonneland A, Hansen L, et al. (2015) An epidemiologic risk prediction model for ovarian cancer in Europe: the EPIC study. British journal of cancer 112(7): 1257-1265

40. Riman T, Persson I, Nilsson S (1998) Hormonal aspects of epithelial ovarian cancer: review of epidemiological evidence. Clinical endocrinology 49(6): 695-707.

41. Brekelmans CT (2003) Risk factors and risk reduction of breast and ovarian cancer. Current opinion in obstetrics \& gynecology 15(1): 63-68

42. Beral V, Million Women Study C, Bull D, Green J, Reeves G (2007) Ovarian cancer and hormone replacement therapy in the Million Women Study. Lancet 369(9574): 1703-1710.

43. Riman T, Nilsson S, Persson IR (2004) Review of epidemiological evidence for reproductive and hormonal factors in relation to the risk of epithelial ovarian malignancies. Acta obstetricia et gynecologica Scandinavica 83(9): 783-795.

44. Morch LS, Lokkegaard E, Andreasen AH, Kjaer SK, Lidegaard O (2012) Hormone therapy and ovarian borderline tumors: a national cohort study. Cancer causes \& control 23(1): 113-120.

45. Morch LS, Lokkegaard E, Andreasen AH, Kruger Kjaer S, Lidegaard O (2009) Hormone therapy and ovarian cancer. Jama 302(3): 298-305.

46. Folsom AR, Anderson JP, Ross JA (2004) Estrogen replacement therapy and ovarian cancer. Epidemiology 15(1): 100-104.

47. Rodriguez C, Calle EE (2002) Postmenopausal hormone replacement body mass index, and quality of life. Jama 287(17): 2210-2211.

48. Li L, Ji J, Wang JB, Niyazi M, Qiao YL, et al. (2012) Attributable causes of breast cancer and ovarian cancer in china: reproductive factors, oral contraceptives and hormone replacement therapy. Chinese journal of cancer research 24(1): 9-17.

49. Tsilidis KK, Allen NE, Key TJ, Dossus L, Kaaks R, et al. (2011) Menopausal hormone therapy and risk of ovarian cancer in the European prospective investigation into cancer and nutrition. Cancer causes \& control 22(8): 1075-1084.

50. Morch LS, Lokkegaard E, Andreasen AH, Kjaer SK, Lidegaard O (2012) Hormone therapy and different ovarian cancers: a national cohort study. American journal of epidemiology 175(12): 1234-1242.

51. Modugno F, Ness RB, Allen GO, Schildkraut JM, Davis FG, et al. (2004) Oral contraceptive use, reproductive history, and risk of epithelial ovarian cancer in women with and without endometriosis. Am J Obstet Gynecol 191(3): 733-740.
52. Melin A, Sparen P, Persson I, Bergqvist A (2006) Endometriosis and the risk of cancer with special emphasis on ovarian cancer. Human reproduction 21(5): 1237-1242.

53. Melin A, Sparen P, Bergqvist A (2007) The risk of cancer and the role of parity among women with endometriosis. Human reproduction 22(11): 3021-3026.

54. Tsilidis KK, Allen NE, Key TJ, Dossus L, Lukanova A, et al. (2011) Oral contraceptive use and reproductive factors and risk of ovarian cancer in the European Prospective Investigation into Cancer and Nutrition. British journal of cancer 105(9): 1436-1442.

55. Li L, Pan Z, Gao K, Zhang W, Luo Y, et al. (2012) Impact of post-operative hormone replacement therapy on life quality and prognosis in patients with ovarian malignancy. Oncol Lett 3(1): 244-249.

56. Faber MT, Kjaer SK, Dehlendorff C, Chang Claude J, Andersen KK, et al. (2013) Cigarette smoking and risk of ovarian cancer: a pooled analysis of 21 case-control studies. Cancer causes \& control: CCC 24(5): 989-1004.

57. Weiderpass E, Sandin S, Inoue M, Shimazu T, Iwasaki M, et al. (2012) Risk factors for epithelial ovarian cancer in Japan - results from the Japan Public Health Center-based Prospective Study cohort. International journal of oncology 40(1): 21-30.

58. Harris HR, Titus LJ, Cramer DW, Terry KL (2017) Long and irregular menstrual cycles, polycystic ovary syndrome, and ovarian cancer risk in a population-based case-control study. International journal of cancer Journal international du cancer 140(2): 285-291.

59. Schildkraut JM, Schwingl PJ, Bastos E, Evanoff A, Hughes C (1996) Epithelial ovarian cancer risk among women with polycystic ovary syndrome. Obstetrics and gynecology 88(4): 554-559.

60. Barry JA, Azizia MM, Hardiman PJ (2014) Risk of endometrial, ovarian and breast cancer in women with polycystic ovary syndrome: a systematic review and meta-analysis. Human reproduction update 20(5): 748-758

61. Shen CC, Yang AC, Hung JH, Hu LY, Tsai SJ (2015) A nationwide population-based retrospective cohort study of the risk of uterine, ovarian and breast cancer in women with polycystic ovary syndrome. The oncologist 20(1): 45-49.

62. Dennefors BL, Knutson F, Janson PO, Jansson I, Hamberger L (1985) Ovarian steroid production in a woman with polycystic ovary syndrome associated with endometrial cancer. Acta obstetricia et gynecologica Scandinavica 64(5): 387-392.

63. Lukanova A, Kaaks R (2005) Endogenous hormones and ovarian cancer: epidemiology and current hypotheses. Cancer epidemiology, biomarkers \& prevention: a publication of the American Association for Cancer Research, cosponsored by the American Society of Preventive Oncology 14(1): 98-107.

64. Pasalich M, Su D, Binns CW, Lee AH (2013) Reproductive factors for ovarian cancer in southern Chinese women. Journal of gynecologic oncology 24(2): 135-140.

65. Fauvet R, Dufournet Etienne C, Poncelet C, Bringuier AF, Feldmann G et al. (2006) Effects of progesterone and anti-progestin (mifepristone) treatment on proliferation and apoptosis of the human ovarian cancer cell line, OVCAR-3. Oncology reports 15(4): 743-748.

66. Yu S, Lee M, Shin S, Park J (2001) Apoptosis induced by progesterone in human ovarian cancer cell line SNU-840. Journal of cellular biochemistry 82(3): 445-451.

67. Syed V, Mukherjee K, Godoy Tundidor S, Ho SM (2007) Progesterone induces apoptosis in TRAIL-resistant ovarian cancer cells by circumventing c-FLIPL overexpression. Journal of cellular biochemistry 102(2): 442-452.

68. Hu Z, Deng X (2000) The effect of progesterone on proliferation and apoptosis in ovarian cancer cell]. Zhonghua fu chan ke za zhi 35(7): 423 426. 
69. Lee JY, Shin JY, Kim HS, Heo JI, Kho YJ, et al. (2012) Effect of combined treatment with progesterone and tamoxifen on the growth and apoptosis of human ovarian cancer cells. Oncology reports 27(1): 87-93.

70. Nguyen H, Syed V (2011) Progesterone inhibits growth and induces apoptosis in cancer cells through modulation of reactive oxygen species. Gynecological endocrinology : the official journal of the International Society of Gynecological Endocrinology 27(10): 830-836.

71. Blumenthal M, Kardosh A, Dubeau L, Borok Z, Schonthal AH (2003) Suppression of the transformed phenotype and induction of differentiation-like characteristics in cultured ovarian tumor cells by chronic treatment with progesterone. Molecular carcinogenesis 38(4): 160-169.

72. Syed V, Mukherjee K, Lyons Weiler J, Lau KM, Mashima T, et al. (2005) Identification of ATF-3, caveolin-1, DLC-1, and NM23-H2 as putative antitumorigenic, progesterone-regulated genes for ovarian cancer cells by gene profiling. Oncogene 24(10): 1774-1787.

73. Hua K, Feng W, Cao Q, Zhou X, Lu X, et al. (2008) Estrogen and progestin regulate metastasis through the PI3K/AKT pathway in human ovarian cancer. International journal of oncology 33(5): 959-967.

74. Hua KQ, Yao LQ, Cao Q, Huang Y, Zhao YQ, et al. (2006) Influence of estrogen and progestin on nm23-H1 expression in epithelial ovarian cancer cell lines via activation of phosphorylation signaling]. Zhonghua fu chan ke za zhi 41(11): 756-761.

75. Diep CH, Charles NJ, Gilks CB, Kalloger SE, Argenta PA, et al. (2013) Progesterone receptors induce FOXO1-dependent senescence in ovarian cancer cells. Cell cycle 12(9): 1433-1449.

76. Lindgren PR, Cajander S, Backstrom T, Gustafsson JA, Makela S, Olofsson JI (2004) Estrogen and progesterone receptors in ovarian epithelial tumors. Molecular and cellular endocrinology 221(1-2): 97-104.

77. Risch HA (1998) Hormonal etiology of epithelial ovarian cancer, with a hypothesis concerning the role of androgens and progesterone. Journal of the National Cancer Institute 90(23): 1774-1786.

78. Sieh W, Kobel M, Longacre TA, Bowtell DD, de Fazio A, et al. (2013) Hormone-receptor expression and ovarian cancer survival: an Ovarian Tumor Tissue Analysis consortium study. The Lancet Oncology 14(9): 853-862.

79. Laviolette LA, Garson K, Macdonald EA, Senterman MK, Courville K, et al. (2010) 17beta-estradiol accelerates tumor onset and decreases survival in a transgenic mouse model of ovarian cancer. Endocrinology 151(3): 929-938.

80. Spillman MA, Manning NG, Dye WW, Sartorius CA, Post MD, et al. (2010) Tissue-specific pathways for estrogen regulation of ovarian cancer growth and metastasis. Cancer research 70(21): 8927-8936.

81. Mc Guire PA, Conklin BH, Webb DI (1996) Prevention of ovarian cancer with bilateral oophorectomy at time of hysterectomy. Alaska medicine 38(2): 69-70,81.

82. Charoenkwan K, Srisomboon J, prasert P, Phongnarisorn C, Siriaree S, et al. (2004) Role of prophylactic oophorectomy at the time of hysterectomy in ovarian cancer prevention in Thailand. The journal of obstetrics and gynaecology research 30(1): 20-23.

83. Ruppitsch U, Petru E, Woltsche M, Pickel H, Lahousen M (1991) The value of preventive ovariectomy at the time of hysterectomy for prevention of ovarian cancer]. Gynakologische Rundschau 31(2): 289-290.

84. Madsen C, Baandrup L, Dehlendorff C, Kjaer SK (2015) Tubal ligation and salpingectomy and the risk of epithelial ovarian cancer and borderline ovarian tumors: a nationwide case-control study. Acta obstetricia et gynecologica Scandinavica 94(1): 86-94.

85. Rice MS, Hankinson SE, Tworoger SS (2014) Tubal ligation, hysterectomy, unilateral oophorectomy, and risk of ovarian cancer in the Nurses Health Studies. Fertility and sterility 102(1): 192-198, e3.
86. Syed V, Zhang X, Lau KM, Cheng R, Mukherjee K, et al. (2005) Profiling estrogen-regulated gene expression changes in normal and malignant human ovarian surface epithelial cells. Oncogene 24(55): 8128-8143.

87. Li AJ, Elmore RG, Pavelka JC, Karlan BY (2007) Hyperandrogenism, mediated by obesity and receptor polymorphisms, promotes aggressive epithelial ovarian cancer biology. Gynecologic oncology 107(3): 420423.

88. Lee AW, Tyrer JP, Doherty JA, Stram DA, Kupryjanczyk J, et al. (2015) Evaluating the ovarian cancer gonadotropin hypothesis: a candidate gene study. Gynecologic oncology 136(3): 542-548.

89. Moore MA, Park CB, Tsuda H 1(998) Implications of the hyperinsulinaemia-diabetes-cancer link for preventive efforts. European journal of cancer prevention : the official journal of the European Cancer Prevention Organisation 7(3): 89-107.

90. Giovannucci E (1995) Insulin and colon cancer. Cancer causes \& control : CCC 6(2): 164-179.

91. Giovannucci E (2001) Insulin, insulin-like growth factors and colon cancer: a review of the evidence. The Journal of nutrition 131(11): 3109S-3120S

92. Yu H, Rohan T (2000) Role of the insulin-like growth factor family in cancer development and progression. Journal of the National Cancer Institute 92(18): 1472-1489.

93. Kaaks R, Lukanova A (2001) Energy balance and cancer: the role of insulin and insulin-like growth factor-I. Proc Nutr Soc 60(1): 91-106.

94. Schoen RE, Tangen CM, Kuller LH, Burke GL, Cushman M, et al. (1999) Increased blood glucose and insulin, body size, and incident colorectal cancer. Journal of the National Cancer Institute 91(13): 1147-1154.

95. Troisi R, Potischman N, Hoover RN, Siiteri P, Brinton LA (1997) Insulin and endometrial cancer. American journal of epidemiology146(6): 476482.

96. Stronach EA, Cunnea P, Turner C, Guney T, Aiyappa R, et al. (2015) The role of interleukin-8 (IL-8) and IL-8 receptors in platinum response in high grade serous ovarian carcinoma. Oncotarget 6(31): 31593-31603.

97. Schauer IG, Zhang J, Xing Z, Guo X, Mercado Uribe I, et al. (2013) Interleukin-1beta promotes ovarian tumorigenesis through a p53/ NF-kappaB-mediated inflammatory response in stromal fibroblasts. Neoplasia 15(4): 409-420.

98. Coward J, Kulbe H, Chakravarty P, Leader D, Vassileva V, et al. (2011) Interleukin- 6 as a therapeutic target in human ovarian cancer. Clinical cancer research : an official journal of the American Association for Cancer Research 17(18): 6083-6096.

99. Kumar J, Ward AC (2014) Role of the interleukin 6 receptor family in epithelial ovarian cancer and its clinical implications. Biochim Biophys Acta 1845(2): 117-125.

100. Li Z, Sandau CD, Romanoff LC, Caudill SP, Sjodin A, et al. (2008) Concentration and profile of 22 urinary polycyclic aromatic hydrocarbon metabolites in the US population. Environmental research 107(3): 320-331.

101. Hecht SS (1999) Tobacco smoke carcinogens and lung cancer. Journal of the National Cancer Institute 91(14): 1194-1210.

102. Purcaro G, Moret S, Conte LS (2013) Overview on polycyclic aromatic hydrocarbons: occurrence, legislation and innovative determination in foods. Talanta 105: 292-305.

103. Senturk Z (2013) Analysis of carcinogenic Polycyclic Aromatic Hydrocarbons (PAHS): an overview of modern electroanalytical techniques and their applications. Current drug delivery 10(1): 76-91.

104. Lim J, Lawson GW, Nakamura BN, Ortiz L, Hur JA, et al. (2013) Glutathione-deficient mice have increased sensitivity to transplacental 
benzo[a]pyrene-induced premature ovarian failure and ovarian tumorigenesis. Cancer research 73(2): 908-917.

105. Curtis L, Rea W, Smith Willis P, Fenyves E, Pan Y (2006) Adverse health effects of outdoor air pollutants. Environment international 32(6): 815-830.

106. Scheepers PT, van Houtum J, Anzion RB, Champmartin C, Hertsenberg $S$, et al. (2009) The occupational exposure of dermatology nurses to polycyclic aromatic hydrocarbons - evaluating the effectiveness of better skin protection. Scandinavian journal of work, environment \& health 35(3): 212-221.

107. Kubasiewicz M, Starzynski Z, Szymczak W (1991) Case-referent study on skin cancer and its relation to occupational exposure to polycyclic aromatic hydrocarbons. II. Study results. Polish journal of occupational medicine and environmental health 4(2): 141-147.

108. Adetunde OT, Mills GA, Olayinka KO, Alo BI (2014) Assessment of occupational exposure to polycyclic aromatic hydrocarbons via involuntary ingestion of soil from contaminated soils in Lagos, Nigeria. Journal of environmental science and health Part A, Toxic/hazardous substances \& environmental engineering 49(14): 1661-1671.

109. Mirsadeghi SA, Zakari MP, Yap CK, Shahbazi A (2011) Risk assessment for the daily intake of polycyclic aromatic hydrocarbons from the ingestion of cockle (Anadara granosa) and exposure to contaminated water and sediments along the west coast of Peninsular Malaysia. Journal of environmental sciences 23(2): 336-345.

110. Hung LJ, Chan TF, Wu CH, Chiu HF, Yang CY (2012) Traffic air pollution and risk of death from ovarian cancer in Taiwan: fine particulate matter (PM2.5) as a proxy marker. Journal of toxicology and environmenta health Part A 75(3): 174-182.

111. Krewski D, Rainham D (2007) Ambient air pollution and population health: overview. Journal of toxicology and environmental health Part A 70(3-4): 275-283.

112. Garcia Perez J, Lope V, Lopez Abente G, Gonzalez Sanchez M, Fernandez Navarro P (2015) Ovarian cancer mortality and industrial pollution. Environmental pollution 205: 103-110.

113. Shi R, Yan L, Xu T, Liu D, Zhu Y, et al. (2015) Graphene oxide bound silica for solid-phase extraction of 14 polycyclic aromatic hydrocarbons in mainstream cigarette smoke. Journal of chromatography A 1375: 1-7.

114. Schick SF, Farraro KF, Perrino C, Sleiman M, van de Vossenberg G, et al. (2014) Thirdhand cigarette smoke in an experimental chamber: evidence of surface deposition of nicotine, nitrosamines and polycyclic aromatic hydrocarbons and de novo formation of NNK. Tobacco control 23(2): 152-159.

115. Wang X, Wang Y, Qin Y, Ding L, Chen Y, et al. (2015) Sensitive and selective determination of polycyclic aromatic hydrocarbons in mainstream cigarette smoke using a graphene-coated solid-phase microextraction fiber prior to GC/MS. Talanta 140: 102-108.

116. Phillips DH (2005) DNA adducts as markers of exposure and risk. Mutation research 577(1-2): 284-292.

117. Baird WM, Hooven LA, Mahadevan B (2005) Carcinogenic polycyclic aromatic hydrocarbon-DNA adducts and mechanism of action. Environmental and molecular mutagenesis 45(2-3): 106-114.

118. Mancini R, Romano G, Sgambato A, Flamini G, Giovagnoli MR, et al. (1999) Polycyclic aromatic hydrocarbon-DNA adducts in cervical smears of smokers and nonsmokers. Gynecologic oncology 75(1): 6871.

119. McCarty KM, Santella RM, Steck SE, Cleveland RJ, Ahn J, et al. (2009) PAH-DNA adducts, cigarette smoking, GST polymorphisms, and breast cancer risk. Environmental health perspectives 117(4): 552-558.

120. Gammon MD, Santella RM (2008) PAH, genetic susceptibility and breast cancer risk: an update from the Long Island Breast Cancer Study Project. European journal of cancer 44(5): 636-640.
121. White AJ, Chen J, McCullough LE, Xu X, Cho YH, et al. (2015) Polycyclic aromatic hydrocarbon (PAH)-DNA adducts and breast cancer: modification by gene promoter methylation in a population-based study. Cancer causes \& control: CCC 26(12): 1791-1802.

122. Scialli AR, Watkins DK, Ginevan ME (2015) Agent Orange Exposure and 2,3,7,8-Tetrachlorodibenzo-p-Dioxin (TCDD) in Human Milk. Birth defects research Part B, Developmental and reproductive toxicology 104(3): 129-139.

123. Armitage JM, Ginevan ME, Hewitt A, Ross JH, Watkins DK, et al. (2015) Environmental fate and dietary exposures of humans to TCDD as a result of the spraying of Agent Orange in upland forests of Vietnam. The Science of the total environment 506-507: 621-630.

124. Ross JH, Hewitt A, Armitage J, Solomon K, Watkins DK, et al. (2015) Exposure to TCDD from base perimeter application of Agent Orange in Vietnam. The Science of the total environment 511: 82-90.

125. Steenland K, Deddens J, Piacitelli L (2001) Risk assessment for 2,3,7,8-tetrachlorodibenzo-p-dioxin (TCDD) based on an epidemiologic study. American journal of epidemiology 154(5): 451-458.

126. Maronpot RR, Foley JF, Takahashi K, Goldsworthy T, Clark G, et al. (1993) Dose response for TCDD promotion of hepatocarcinogenesis in rats initiated with DEN: histologic, biochemical, and cell proliferation endpoints. Environmental health perspectives 101(7): 634-642.

127. Chang ET, Boffetta P, Adami HO, Cole P, Mandel JS (2014) A critical review of the epidemiology of Agent Orange/TCDD and prostate cancer. European journal of epidemiology 29(10): 667-723.

128. Mandavia C (2015) TCDD-induced activation of aryl hydrocarbon receptor regulates the skin stem cell population. Medical hypotheses 84(3): 204-208.

129. De Abrew KN, Thomas Virnig CL, Rasmussen CA, Bolterstein EA, Schlosser SJ, et al. (2014) TCDD induces dermal accumulation of keratinocyte-derived matrix metalloproteinase-10 in an organotypic model of human skin. Toxicology and applied pharmacology 276(3): 171-178.

130. Tuomisto JT, Pohjanvirta R, Unkila M, Tuomisto J (1999) TCDD-induced anorexia and wasting syndrome in rats: effects of diet-induced obesity and nutrition. Pharmacology, biochemistry, and behavior 62(4): 735742 .

131. Hsia MT, Kreamer BL (1985) Delayed wasting syndrome and alterations of liver gluconeogenic enzymes in rats exposed to the TCDD congener 3,3', 4,4'-tetrachloroazoxybenzene. Toxicology letters 25(3): 247-258.

132. Williams SR, Son DS, Terranova PF (2004) Protein kinase C delta is activated in mouse ovarian surface epithelial cancer cells by 2,3,7,8-tetrachlorodibenzo-p-dioxin (TCDD). Toxicology 195(1): 1-17.

133. Davis BJ, McCurdy EA, Miller BD, Lucier GW, Tritscher AM (2000) Ovarian tumors in rats induced by chronic 2,3,7,8-tetrachlorodibenzop-dioxin treatment. Cancer research 60(9): 5414-5419.

134. Takahashi S, Hirano S, Ito N, Tamaya T (2005) Effects of dioxin and nutrition on cellular proliferation and dioxin- and estrogen-linked genes in ovarian cancer cell lines. European journal of gynaecological oncology 26(2): 175-180.

135. Heimler I, Trewin AL, Chaffin CL, Rawlins RG, Hutz RJ (1998) Modulation of ovarian follicle maturation and effects on apoptotic cell death in Holtzman rats exposed to 2,3,7,8-tetrachlorodibenzop-dioxin (TCDD) in utero and lactationally. Reproductive toxicology 12(1): 69-73.

136. Wang C, Xu CX, Bu Y, Bottum KM, Tischkau SA (2014) Betanaphthoflavone (DB06732) mediates estrogen receptor-positive breast cancer cell cycle arrest through AhR-dependent regulation of PI3K/AKT and MAPK/ERK signaling. Carcinogenesis 35(3): 703-713.

137. Davis JW, Melendez K, Salas VM, Lauer FT, Burchiel SW (2000) 2,3,7,8-Tetrachlorodibenzo-p-dioxin (TCDD) inhibits growth factor 
withdrawal-induced apoptosis in the human mammary epithelial cell line, MCF-10A. Carcinogenesis 21(5): 881-886.

138. Li Y, Wang K, Jiang YZ, Chang XW, Dai CF, et al. (2014) 2,3,7,8-Tetrachlorodibenzo-p-dioxin (TCDD) inhibits human ovarian cancer cell proliferation. Cellular oncology 37(6): 429-437.

139. Goodman MT, Tung KH (2003) Active and passive tobacco smoking and the risk of borderline and invasive ovarian cancer (United States). Cancer causes \& control : CCC 14(6): 569-577.

140. Tworoger SS, Gertig DM, Gates MA, Hecht JL, Hankinson SE (2008) Caffeine, alcohol, smoking, and the risk of incident epithelial ovarian cancer. Cancer 112(5): 1169-1177.

141. Gram IT, Braaten T, Adami HO, Lund E, Weiderpass E (2008) Cigarette smoking and risk of borderline and invasive epithelial ovarian cancer International journal of cancer Journal international du cancer 122(3): 647-652.

142. Rossing MA, Cushing Haugen KL, Wicklund KG, Weiss NS (2008) Cigarette smoking and risk of epithelial ovarian cancer. Cancer causes \& control: CCC 19(4): 413-420.

143. Beral V, Gaitskell K, Hermon C, Moser K, Reeves G, et al. (2012) Ovarian cancer and smoking: individual participant meta-analysis including 28,114 women with ovarian cancer from 51 epidemiological studies. The Lancet Oncology 13(9): 946-956.

144. Olsen CM, Green AC, Whiteman DC, Sadeghi S, Kolahdooz F, et al. (2007) Obesity and the risk of epithelial ovarian cancer: a systematic review and meta-analysis. European journal of cancer 43(4): 690-709.

145. Olsen CM, Nagle CM, Whiteman DC, Ness R, Pearce CL (2013) Obesity and risk of ovarian cancer subtypes: evidence from the Ovarian Cancer Association Consortium. Endocrine-related cancer 20(2): 251-262.

146. Chionh F, Baglietto L, Krishnan K, English DR, MacInnis RJ, et al. (2010) Physical activity, body size and composition, and risk of ovarian cancer. Cancer causes \& control : CCC 21(12): 2183-2194.

147. Lahmann PH, Cust AE, Friedenreich CM, Schulz M, Lukanova A, et al. (2010) Anthropometric measures and epithelial ovarian cancer risk in the European Prospective Investigation into Cancer and Nutrition. International journal of cancer Journal international du cancer 126(10): 2404-2415.

148. Makowski L, Zhou C, Zhong Y, Kuan PF, Fan C, et al. (2014) Obesity increases tumor aggressiveness in a genetically engineered mouse model of serous ovarian cancer. Gynecologic oncology 133(1): 90-97.

149. Brandstedt J, Nodin B, Manjer J, Jirstrom K (2011) Anthropometric factors and ovarian cancer risk in the Malmo Diet and Cancer Study. Cancer epidemiology 35(5): 432-437.

150. Kotsopoulos J, Baer HJ, Tworoger SS (2010) Anthropometric measures and risk of epithelial ovarian cancer: results from the nurses' health study. Obesity 18(8): 1625-1631.

151. Canchola AJ, Chang ET, Bernstein L, Largent JA, Reynolds P, et al. (2010) Body size and the risk of ovarian cancer by hormone therapy use in the California Teachers Study cohort. Cancer causes \& control : CCC 21(12): 2241-2248.

152. Lee AH, Su D, Pasalich M, Wong YL, Binns CW (2013) Habitual physical activity reduces risk of ovarian cancer: a case-control study in southern China. Preventive medicine 57 Suppl: S31-33.

153. Cannioto RA, Moysich KB (2015) Epithelial ovarian cancer and recreational physical activity: A review of the epidemiological literature and implications for exercise prescription. Gynecologic oncology 137(3): 559-573.

154. Abbott SE, Bandera EV, Qin B, Peres LC, Moorman PG, et al. (2016) Recreational physical activity and ovarian cancer risk in African American women. Cancer medicine 5(6): 1319-1327.
155. Zhou LM (2014) Recreational physical activity and risk of ovarian cancer: a meta-analysis. Asian Pacific journal of cancer prevention : APJCP 15(13): 5161-5166.

156. Zhong S, Chen L, Lv M, Ma T, Zhang X, et al. (2014) Nonoccupational physical activity and risk of ovarian cancer: a meta-analysis. Tumour biology : the journal of the International Society for Oncodevelopmental Biology and Medicine 35(11): 11065-11073.

157. Cannioto RA, LaMonte MJ, Kelemen LE, Risch HA, Eng KH, et al. (2016) Recreational physical inactivity and mortality in women with invasive epithelial ovarian cancer: evidence from the Ovarian Cancer Association Consortium. British journal of cancer 115(1): 95-101.

158. Zhou Y, Chlebowski R, LaMonte MJ, Bea JW, Qi L, et al. (2014) Body mass index, physical activity, and mortality in women diagnosed with ovarian cancer: results from the Women's Health Initiative. Gynecologic oncology 133(1): 4-10.

159. Smits A, Smits E, Lopes A, Das N, Hughes G, et al. (2015) Body mass index, physical activity and quality of life of ovarian cancer survivors: time to get moving? Gynecologic oncology 139(1):148-154.

160. Huang T, Eliassen AH, Hankinson SE, Okereke OI, Kubzansky LD, et al. (2016) A prospective study of leisure-time physical activity and risk of incident epithelial ovarian cancer: Impact by menopausal status. International journal of cancer Journal international du cancer 138(4): 843-852.

161. Hildebrand JS, Gapstur SM, Gaudet MM, Campbell PT, Patel AV (2015) Moderate-to-vigorous physical activity and leisure-time sitting in relation to ovarian cancer risk in a large prospective US cohort. Cancer causes \& control : CCC 26(11): 1691-1697.

162. Xiao Q, Yang HP, Wentzensen N, Hollenbeck A, Matthews CE (2013) Physical activity in different periods of life, sedentary behavior, and the risk of ovarian cancer in the NIH-AARP diet and health study. Cancer epidemiology, biomarkers \& prevention : a publication of the American Association for Cancer Research, cosponsored by the American Society of Preventive Oncology 22(11): 2000-2008.

163. Gurr MI (1999) Diet and the prevention of cancer. No evidence has linked ovarian cancer with high intakes of fat and meat. Bmj 319: 187188.

164. Cowen S, McLaughlin SL, Hobbs G, Coad J, Martin KH, et al. (2015) High-Fat, High-Calorie Diet Enhances Mammary Carcinogenesis and Local Inflammation in MMTV-PyMT Mouse Model of Breast Cancer. Cancers (Basel) 7(3): 1125-1142.

165. Andrade Fde O, de Assis S, Jin L, Fontelles CC, Barbisan LF, et al. (2015) Lipidomic fatty acid profile and global gene expression pattern in mammary gland of rats that were exposed to lard-based high fat diet during fetal and lactation periods associated to breast cancer risk in adulthood. Chem Biol Interact 239: 118-128.

166. Hertzman C, Teschke K, Ostry A, Hershler R, Dimich Ward H, et al. (1997) Mortality and cancer incidence among sawmill workers exposed to chlorophenate wood preservatives. Am J Public Health 87(1): 71-79.

167. Sinha R, Rothman N (1999) Role of well-done, grilled red meat, heterocyclic amines (HCAs) in the etiology of human cancer. Cancer letters 143(2): 189-194.

168. Han B, Li X, Yu T (2014) Cruciferous vegetables consumption and the risk of ovarian cancer: a meta-analysis of observational studies. Diagnostic pathology 9: 7.

169. Trudel D, Labbe DP, Bairati I, Fradet V, Bazinet L, et al. (2012) Green tea for ovarian cancer prevention and treatment: a systematic review of the in vitro, in vivo and epidemiological studies. Gynecologic oncology 126(3): 491-498.

170. Zhang M, Lee AH, Binns CW, Xie X (2004) Green tea consumption enhances survival of epithelial ovarian cancer. International journal of 
cancer Journal international du cancer 112(3): 465-469.

171. Zhang M, Xie X, Lee AH, Binns CW (2004) Soy and isoflavone intake are associated with reduced risk of ovarian cancer in southeast china. Nutrition and cancer 49(2): 125-130.

172. Lee AH, Su D, Pasalich M, Tang L, Binns CW, Qiu L (2014) Soy and isoflavone intake associated with reduced risk of ovarian cancer in southern Chinese women. Nutrition research 34(4): 302-307.

173. Rouhana-Toubi A, Wasser SP, Agbarya A, Fares F (2013) Inhibitory effect of ethyl acetate extract of the shaggy inc cap medicinal mushroom, Coprinus comatus (Higher Basidiomycetes) fruit bodies on cell growth of human ovarian cancer. International journal of medicinal mushrooms 15(5): 457-470.

174. Lee AH, Pasalich M, Su D, Tang L, Tran VD, et al. (2013) Mushroom intake and risk of epithelial ovarian cancer in southern Chinese women. International journal of gynecological cancer : official journal of the International Gynecological Cancer Society 23(8): 1400-1405.

175. Hiratsuka A, Sebata N, Kawashima K, Okuda H, Ogura K, et al. (1990) A new class of rat glutathione $S$-transferase Yrs-Yrs inactivating reactive sulfate esters as metabolites of carcinogenic arylmethanols. The Journal of biological chemistry 265(20): 11973-11981.

176. Hwang KA, Kang NH, Yi BR, Lee HR, Park MA, et al. (2013) Genistein, a soy phytoestrogen, prevents the growth of BG-1 ovarian cancer cells induced by 17beta-estradiol or bisphenol A via the inhibition of cell cycle progression. International journal of oncology 42(2): 733-740.

177. Yan-Hong H, Jing L, Hong L, Shan-Shan H, Yan L, et al. (2015) Association between alcohol consumption and the risk of ovarian cancer: a metaanalysis of prospective observational studies. BMC public health 15: 223.

178. Cook LS, Leung AC, Swenerton K, Gallagher RP, Magliocco A, et al. (2016) Adult lifetime alcohol consumption and invasive epithelial ovarian cancer risk in a population-based case-control study. Gynecologic oncology 140(2): 277-284.

179. Gwinn ML, Webster LA, Lee NC, Layde PM, Rubin GL (1986) Alcohol consumption and ovarian cancer risk. American journal of epidemiology 123(5): 759-766.

180. Kelemen LE, Bandera EV, Terry KL, Rossing MA, Brinton LA, et al. (2013) Recent alcohol consumption and risk of incident ovarian carcinoma: a pooled analysis of 5,342 cases and 10,358 controls from the Ovarian Cancer Association Consortium. BMC cancer 13: 28.

ISSN: 2574-1241

DOI: 10.26717/BJSTR.2018.11.002076

Wasana Sumanasekera. Biomed J Sci \& Tech Res

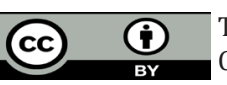

This work is licensed under Creative Commons Attribution 4.0 License

Submission Link: https://biomedres.us/submit-manuscript.php
181. Peterson NB, Trentham-Dietz A, Newcomb PA, Chen Z, Hampton JM, et al. (2006) Alcohol consumption and ovarian cancer risk in a population-based case-control study. International journal of cancer Journal international du cancer 119(10): 2423-2427.

182. Modugno F, Ness RB, Allen GO (2003) Alcohol consumption and the risk of mucinous and nonmucinous epithelial ovarian cancer. Obstetrics and gynecology 102(6): 1336-1343.

183. Goodman MT, Tung KH (2003) Alcohol consumption and the risk of borderline and invasive ovarian cancer. Obstetrics and gynecology 101(6): 1221-1228.

184. Gosvig CF, Kjaer SK, Blaakaer J, Hogdall E, Hogdall C, et al. (2015) Coffee, tea, and caffeine consumption and risk of epithelial ovarian cancer and borderline ovarian tumors: Results from a Danish casecontrol study. Acta oncologica 54(8): 1144-1151.

185. Tai J, Cheung S, Chan E, Hasman D (2010) Antiproliferation effect of commercially brewed coffees on human ovarian cancer cells in vitro. Nutrition and cancer 62(8): 1044-1057.

186. Zhu Y, Alvarez C, Doll R, Kurata H, Schebye XM, et al. (2004) Intra-Sphase checkpoint activation by direct CDK2 inhibition. Molecular and cellular biology 24(14): 6268-6277.

187. Song YJ, Kristal AR, Wicklund KG, Cushing-Haugen KL, Rossing M (2008) Coffee, tea, colas, and risk of epithelial ovarian cancer. Cancer epidemiology, biomarkers \& prevention: a publication of the American Association for Cancer Research, cosponsored by the American Society of Preventive Oncology 17(3): 712-716.

188. Hashibe M, Galeone C, Buys SS, Gren L, Boffetta P, et al. (2015) Coffee, tea, caffeine intake, and the risk of cancer in the PLCO cohort. British journal of cancer 113(5): 809-816.

189. Braem MG, Onland-Moret NC, Schouten LJ, Tjonneland A, Hansen L, et al. (2012) Coffee and tea consumption and the risk of ovarian cancer: a prospective cohort study and updated meta-analysis. The American journal of clinical nutrition 95(5): 1172-1181.

190. Hamilton A, Piccart M (2000) The contribution of molecular markers to the prediction of response in the treatment of breast cancer: a review of the literature on HER-2, p53 and BCL-2. Ann Oncol 11(6): 647-663.

191. Aunoble B, Sanches R, Didier E, Bignon YJ (2000) Major oncogenes and tumor suppressor genes involved in epithelial ovarian cancer (review). International journal of oncology 16(3): 567-576.

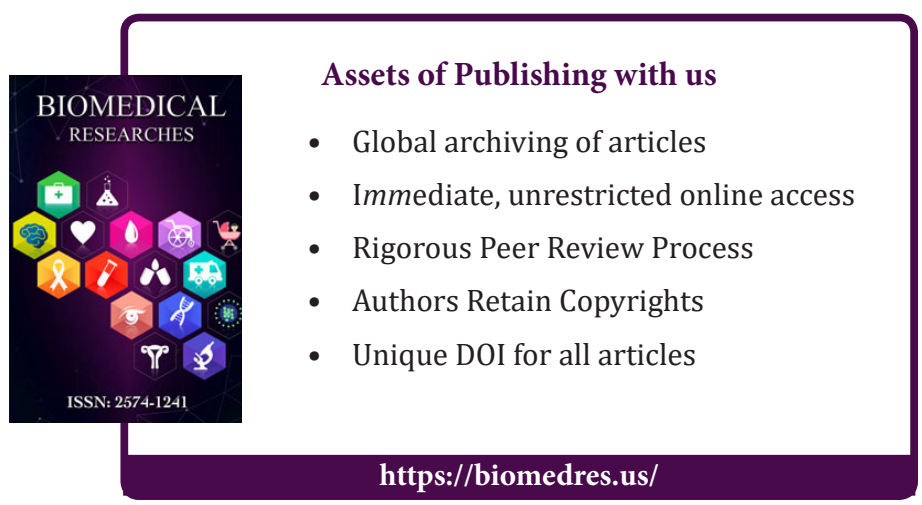

